\title{
Marine diatoms from Buenos Aires coastal waters (Argentina). II. Thalassionemataceae and Rhaphoneidaceae
}

\author{
Diatomeas marinas de aguas costeras de la Provincia de Buenos Aires (Argentina). \\ II. Thalassionemataceae y Rhaphoneidaceae
}

EUGENIA A. SAR ${ }^{1 *}$, INÉS SUNESEN \& PAULA V. FERNÁNDEZ

\author{
Departamento Científico Ficología, Facultad de Ciencias Naturales y Museo, Universidad Nacional de La Plata, \\ Paseo del Bosque s/n, 1900 La Plata, Argentina \\ ${ }^{1}$ Consejo Nacional de Investigaciones Científicas y Técnicas \\ *e-mail for correspondence: easar@museo.fcnym.unlp.edu.ar
}

\begin{abstract}
This study describes the diversity of the species belonging to the diatom families Thalassionemataceae Round and Rhaphoneidaceae Forti frequently found in the temperate marine coastal waters of Buenos Aires Province, Argentina, from October 1994 to September 2000. It comprises morphological, taxonomic and distributional analysis of species found in planktonic samples collected at San Clemente del Tuyú, Santa Teresita, La Lucila del Mar, Mar de Ajó, Nueva Atlantis, Pinamar and Villa Gesell. Raw and cleaned samples were analysed with light and scanning electron microscopy. Four taxa of the genus Thalassionema Grunow ex Mereschkowsky amend. Hallegraeff, one of the genus Lioloma Hasle, two of the genus Delphineis Andrews and one of the genus Rhaphoneis Ehrenberg, were identified. Thalassionema pseudonitzschioides (Schuette \& Schrader) Hasle, Thalassionema synedriforme (Greville) Hasle and Lioloma pacificum (Cupp) Hasle in Hasle \& Syvertsen are new records for Argentina.
\end{abstract}

Key words: diatoms, Thalassionemataceae, Thalassionema, Lioloma, Rhaphoneidaceae, Delphineis, Rhaphoneis

\section{RESUMEN}

Este estudio describe la diversidad de especies de diatomeas pertenecientes a las familias Thalassionemataceae Round and Rhaphoneidaceae Forti encontradas frecuentemente en aguas costeras marinas de la Provincia de Buenos Aires, Argentina, entre octubre de 1994 y septiembre de 2000. En él se lleva a cabo el estudio morfológico, taxonómico y distribucional de las especies halladas en muestras planctónicas colectadas en San Clemente del Tuyú, Santa Teresita, La Lucila del Mar, Mar de Ajó, Nueva Atlantis, Pinamar y Villa Gesell. Material sin tratar y tratado fue analizado con microscopio óptico y microscopio electrónico de barrido. Cuatro taxa de Thalassionema Grunow ex Mereschkowsky amend. Hallegraeff, uno de Lioloma Hasle, dos de Delphineis Andrews y uno de Rhaphoneis Ehrenberg, fueron identificados. Thalassionema pseudonitzschioides (Schuette \& Schrader) Hasle, Thalassionema synedriforme (Greville) Hasle y Lioloma pacificum (Cupp) Hasle in Hasle \& Syvertsen son reportadas por primera vez para aguas costeras de Argentina.

Palabras clave: diatomeas, Thalassionemataceae, Thalassionema, Lioloma, Rhaphoneidaceae, Delphineis, Rhaphoneis.

\section{INTRODUCTION}

The family Thalassionemataceae was erected by Round in Round et al. (1990) and according to Hasle \& Syvertsen (1996) includes the planktonic genera Thalassionema Grunow ex Mereschkowsky amend. Hallegraeff, Thalassiothrix Cleve \& Grunow, Trichotoxon
Reid \& Round and Lioloma Hasle. The generic limits of these taxa were clearly established by Hallegraeff (1986) for Thalassionema, Reid \& Round (1987) for Trichotoxon, and Hasle \& Syvertsen (1996) for Lioloma and Thalassiothrix. The most comprehensive study about the morphology, taxonomy and distribution of the Thalassionemataceae was recently presented by 
Hasle (2001). The taxonomic and nomenclatural history of Thalassionema and Thalassiothrix is complex and was explained in detail by Fourtanier \& Kociolek (1999) and Hasle (2001).

According to Round et al. (1990) and Hasle \& Syvertsen (1996) the family Rhaphoneidaceae Forti includes the genera Adoneis Andrews \& Rivera, Delphineis Andrews, Neodelphineis Takano and Rhaphoneis Ehrenberg, that are frequently found in shallow coastal waters stirred up from the bottom. The generic limits between Delphineis and Rhaphoneis were comprehensively established by Andrews (1975, 1977, 1981, 1988).

According to the catalogues of Ferrario \& Galván (1989) and Vouilloud (2003) several authors reported some diatoms belonging to both families from Argentinean marine waters without ultrastructural analysis. As far as we can determine only Sar (1996) includes documentation by electron microscopy about Thalassionema frauenfeldii (Grunow) Hallegraeff and Delphineis surirella Andrews, and Ferrario et al. (2003) analyse the fine morphology of Delphineis minutissima (Hustedt) Simonsen.

In the framework of a monitoring project on harmful toxic and non toxic diatoms from Buenos Aires coastal waters (Argentina), we have focused our attention on the analysis of some of the most abundant arraphid pennate diatoms collected in our sampling, that belong to the families Thalassionemataceae and Rhaphoneidaceae. The purpose of this paper is to provide an account of the genera found in the area with remarks on morphology, taxonomy, and distribution.

\section{MATERIAL AND METHODS}

The analysed material was collected seasonally from October 1994 to October 1996, bimonthly from October 1996 to January 1999 and monthly from September 1999 to September 2000, at several locations along the coast of Buenos Aires Province: San Clemente del Tuyú, Santa Teresita, La Lucila del Mar, Mar de Ajó, Nueva Atlantis, Pinamar and Villa Gesell (Fig. 1, Table 1). In Buenos Aires Province, seawater temperature ranges from $8-24{ }^{\circ} \mathrm{C}$ and the salinity from 31-34.1 psu. Samples for qualitative analysis were taken from the surface layer of the water column (between 0 and $5 \mathrm{~m}$ ) with $30 \mu \mathrm{m}$ net hauls and fixed with $4 \%$ formalin. In the laboratory, the preserved samples were rinsed with distilled water to remove salt and preservatives, and then the organic matter was oxidized according to Hasle \& Fryxell (1970) and Prygiel \& Coste (2000). The cleaned material was mounted for light (LM) and scanning electron microscopy (SEM) according to Ferrario et al. (1995). Permanent mounts for LM were made with Hyrax or Naphrax.

Materials were deposited in the "Colección de Diatomeas Argentinas, Departamento Científico Ficología, Facultad de Ciencias Naturales y Museo, Universidad Nacional de La Plata".

Observations were made with phase contrast microscopes Wild M20 (Switzerland) and Nikon Microphot-FX (Japan). The photomicrographs were obtained using Wild M20 microscope and scanning electron microscopes Jeol JSMT 100 (Japan) and Jeol JSM 6360 LV.

The terminology followed is that recommended by Ross et al. (1979) and Hasle (2001), and the bibliography about the fine structure of diatom frustules used is basically that compiled by Gaul et al. (1993) and Henderson \& Reimer (2003).

\section{RESULTS AND DISCUSSION}

\section{Thalassionemataceae Round}

Thalassionema Grunow ex Mereschkowsky, amend. Hallegraeff 1986. The generytype of this genus is Thalassionema nitzschioides (Grunow). Mereschkowsky. Silva \& Hasle (1997) proposed to conserve the name Synedra nitzschioides with a conserved type material to preserve the current application of the generic name Thalassionema. The conservation was accepted by the XVI International Botanical Congress at St. Louis, and the name Synedra nitzschioides Grunow published in the list of conserved specific names (ICBN, Greuter et al. 2000).

Thalassionema frauenfeldii (Grunow) Hallegraeff (Fig. 2A-K, Table 2). Basionym: Asterionella frauenfeldii Grunow. Hallegraeff, 1986: 62-64, figs 6-14; Hasle, 2001: 22-25, figs 54-67

Cells united by their ends into fan-shaped, stellate or zigzag colonies. Valve outline linear, 
slightly inflated in the middle, narrower towards the head-pole than towards the footpole. Valve face flat, with a wide sternum delimited by a marginal row of areolae placed between it and the valve mantle. Valve mantle unperforated, deep and almost perpendicular to the valve surface. Areolae with internal, circular, small foramina and external depressions partially occluded by simple, unbranched arches. Labiate processes placed one at each pole of the valve. Foot-pole rounded with an external reinforced hole-like apical protrusion (Fig. 2I arrowed) which is the external opening of the labiate process and a marginal ridge formed by confluence of the areolae occlusions. Head-pole with an external, more prominent, hollow, arrowhead-like protrusion (Fig. 2J arrowed) which is the opening of the labiate process and areolae more densely disposed. Internally the slit-like labiate processes lie obliquely situated to the apical axis of the valve (Fig. $2 \mathrm{~K}$ arrowed).

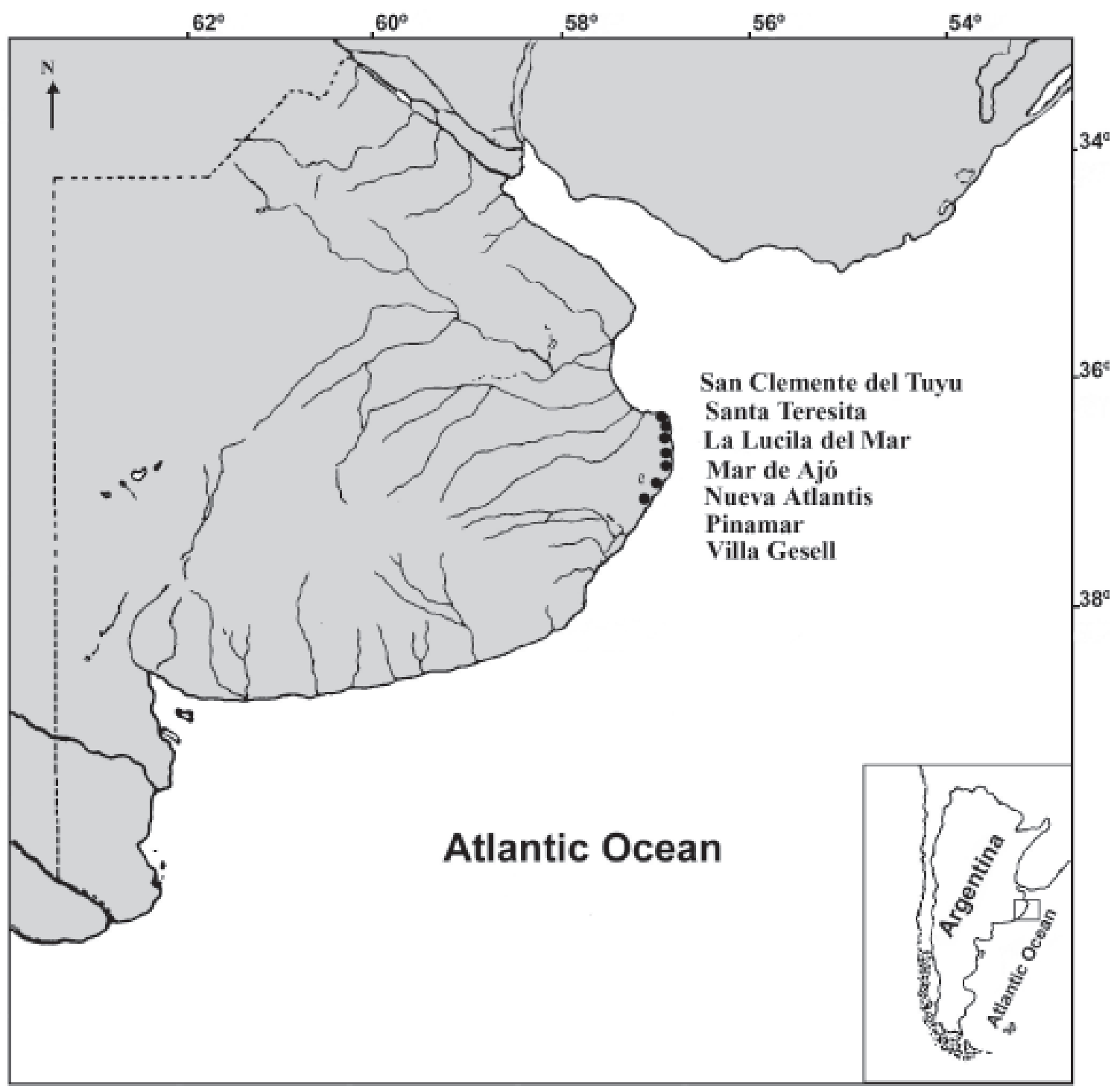

Fig. 1: Map of Buenos Aires Province, showing the sampling stations and location of the area in Argentina.

Mapa de la Provincia de Buenos Aires mostrando las estaciones de muestreo y la localización del área en Argentina. 
TABLE 1

Key to sampling stations, dates of collection and sample numbers at the Colección de Diatomeas Argentinas; SC $=$ San Clemente del Tuyú, ST $=$ Santa Teresita, $\mathrm{LL}=$ La Lucila del Mar, MA = Mar de Ajó, NA = Nueva Atlantis, PI = Pinamar and VG = Villa Gesell

Estaciones de muestreo, fechas de colecta y número con que cada muestra fue depositada en la Colección de Diatomeas Argentinas; $\mathrm{SC}=$ San Clemente del Tuyú, $\mathrm{ST}=$ Santa Teresita, $\mathrm{LL}=$ La Lucila del Mar, MA = Mar de Ajó, NA = Nueva Atlantis, PI = Pinamar y VG = Villa Gesell

\begin{tabular}{|c|c|c|c|c|c|c|c|}
\hline Station & $\mathrm{SC}$ & ST & LL & MA & NA & PI & VG \\
\hline November 1994 & & 4250 & & 4251 & 4252 & & 4253 \\
\hline January 1995 & & 4254 & & 4255 & 4256 & & 4257 \\
\hline March 1995 & & 4258 & & 4259 & 4260 & 4263 & 4264 \\
\hline November 1995 & & 4266 & 4267 & 4268 & 4269 & 4270 & 4271 \\
\hline January 1996 & & 4272 & 4273 & 4274 & 4275 & 4276 & 4277 \\
\hline March 1996 & & & & 4278 & & & \\
\hline April 1996 & 4279 & 4280 & 4281 & 4282 & 4283 & 4284 & 4285 \\
\hline June 1996 & 4286 & 4287 & 4288 & 4289 & & 4290 & 4291 \\
\hline September 1996 & 4292 & 4293 & & 4294 & & 4295 & 4296 \\
\hline November 1996 & 4297 & 4298 & 4299 & 4300 & & & 4301 \\
\hline January 1997 & 4302 & 4303 & 4304 & 4305 & $4306 / 7$ & 4308 & 4309 \\
\hline March 1997 & 4310 & 4311 & 4312 & 4313 & & 4314 & 4315 \\
\hline May 1997 & 4316 & 4317 & 4318 & 4319 & & 4320 & 4321 \\
\hline July 1997 & 4322 & 4323 & 4324 & 4325 & & 4326 & \\
\hline September 1997 & 4327 & 4328 & 4329 & 4330 & & 4331 & \\
\hline November 1997 & 4332 & 4333 & 4334 & 4335 & & 4336 & 4337 \\
\hline January 1998 & 4338 & 4339 & 4340 & 4341 & & 4342 & 4343 \\
\hline March 1998 & 4344 & 4345 & 4346 & 4347 & & 4348 & 4349 \\
\hline May 1998 & 4250 & 4351 & 4352 & 4353 & & 4354 & 4355 \\
\hline July 1998 & 4356 & 4357 & 4358 & 4359 & & 4360 & 4361 \\
\hline September 1998 & 4362 & 4363 & 4364 & 4365 & & 4366 & 4367 \\
\hline December 1998 & 4368 & 4369 & 4370 & 4371 & & 4372 & 4373 \\
\hline January 1999 & 4374 & 4375 & 4376 & 4377 & & 4378 & 4379 \\
\hline September 1999 & 4384 & 4385 & 4386 & 4387 & & 4388 & 4389 \\
\hline November 1999 & 4390 & $4391 / 2$ & 4393 & 4394 & & 4395 & 4396 \\
\hline December 1999 & 4398 & $4399 / 4400$ & 4401 & 4402 & & 4403 & 4404 \\
\hline January 2000 & 4405 & 4406 & 4407 & & & 4408 & 4409 \\
\hline February 2000 & 4410 & $4411 / 2$ & 4413 & 4414 & & 4415 & 4416 \\
\hline March 2000 & 4417 & 4418 & 4419 & 4420 & & 4421 & 4422 \\
\hline April 2000 & 4423 & $4424 / 5$ & 4426 & 4427 & & 4428 & 4429 \\
\hline May 2000 & 4430 & $4431 / 2$ & 4433 & 4434 & & 4435 & 4436 \\
\hline June 2000 & 4437 & 4438 & 4439 & 4440 & & 4441 & 4442 \\
\hline July 2000 & 4443 & 4444 & 4445 & 4446 & & 4447 & 4448 \\
\hline August 2000 & 4449 & 4485 & 4486 & 4487 & & 4488 & 4489 \\
\hline September 2000 & 4490 & 4491 & 4492 & 4493 & & 4494 & 4495 \\
\hline
\end{tabular}



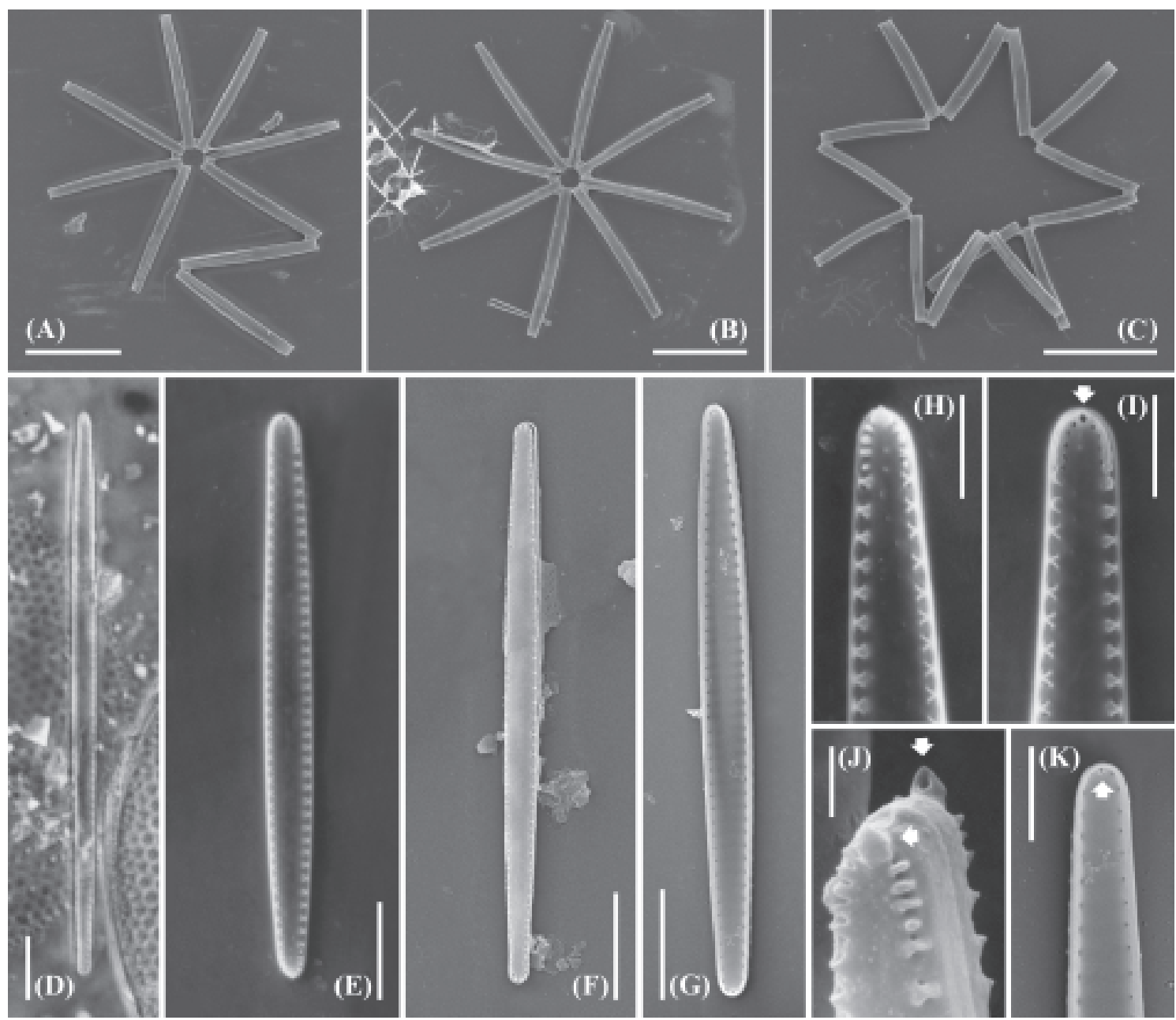

Fig. 2: Thalassionema frauenfeldii. (A-C), (E-K). SEM. (A) and (C): Fan-shaped and zigzag colonies. (B): Stellate colony. (D). LM: Valve showing marginal areolae. (E) and (F): Valves in external view. (G): Valve in internal view. (H) and (I): Details of parts of valve of (E). (H): "Headpole" showing apical spine. (I): Rounded "foot pole" showing reinforced hole-like protrusion and marginal ridge (arrowed). (J): Detail of the "head-pole" of a frustule showing the protrusion (arrowed). (K): Detail of a "foot pole" in internal valve view. Arrow shows labiate process. Scale bars: $(\mathrm{A}-\mathrm{C})=50 \mu \mathrm{m} ;(\mathrm{D}-\mathrm{G})=10 \mu \mathrm{m} ;(\mathrm{H}),(\mathrm{I})$ and $(\mathrm{K})=5 \mu \mathrm{m} ;(\mathrm{J})=2 \mu \mathrm{m}$.

Thalassionema frauenfeldii. (A-C), (E-K). MEB. (A) y (C): Colonias en forma de abanico y zigzag. (B): Colonia estrellada. (D). MO: Valva mostrando areolas marginales. (E) y (F): Valvas en vista externa. (G): Valva en vista interna. (H) y (I): Detalles de partes de la valva de (E). (H): Polo apical mostrando espina. (I): Polo basal redondeado mostrando la salida del proceso con orificio reforzado (flecha) y la costilla marginal. (J): Detalle del polo apical de un frústulo mostrando la protrusión (flechas). (K): Detalle de un polo basal en vista valvar interna. La flecha señala el proceso labiado. Escalas: $(A-C)=50 \mu \mathrm{m} ;(\mathrm{D}-\mathrm{G})=10 \mu \mathrm{m} ;(\mathrm{H}),(\mathrm{I})$ y $(\mathrm{K})=5 \mu \mathrm{m} ;(\mathrm{J})=2 \mu \mathrm{m}$.

Remarks: in coastal waters of the Buenos Aires Province we frequently found specimens of this taxon with a range of length narrower than that described by Hasle (2001), and the majority of them are close to the inferior limit of this range. Additionally, we found specimens wider and with greater areola density.
Distribution in Argentina: this species from warm to temperate waters (Hasle \& Syvertsen 1996) has been found sporadically in all the stations of the study area, as scarce to common, occasionally abundant, all year round. Ferrario \& Galván (1989) enlist several previous records as Thalassiothrix frauenfeldii, based in analysis carried out with light microscopy. 
Subsequently, Sar (1996) reported this species from San Antonio Bay, Río Negro.

Thalassionema nitzschioides (Grunow) Mereschkowsky (Fig. 3A-J, Table 2). Basionym: Synedra nitzschioides Grunow (nom. cons.) Appendix IIIB ICBN (Greuter 2000)

Hallegraeff, 1986: 58-60, figs 1-4; Hasle, 2001: 11-16, figs 1-27. Cells united by the ends into fan-shaped or zigzag-shaped colonies by mucous pads. Frustule, rectangular in girdle view. Valve, elliptic to linear in outline, with similar, smoothly rounded poles. Valve face flat, with a wide sternum delimited by a marginal row of areolae placed between it and the valve mantle. Valve mantle unperforated, deep and almost perpendicular to the valve surface. Areolae with an internal, circular, small foramen and an external depression partially occluded by Yshaped bars with a varying number of lateral branches. Labiate processes placed one at each pole of the valve. Externally they open by apical protrusions, the most prominent is spine-like and the other is a reinforced hole (Fig. 3E arrowed). Internally labiate processes present sessile lips, lying either in or slightly oblique to the apical axis (Figs. $3 \mathrm{H}$, I arrowed).
Remarks: we found specimens with a great variation in length, without significant discontinuities in the range, and with a common fine morphology between smallest and largest valves. The smaller specimens found in our temperate area fit with $T$. nitzschioides var. parva Heiden (Moreno Ruiz \& Licea 1995, Hasle 2001), however, taking into account the variability in length and valve outline and the similarities in areola density and fine morphology observed in all the specimens, we consider that there is no support to maintain the variety parva.

Distribution in Argentina: this cosmopolitan species (Hasle 2001) is the most common in the studied area, it was found in all stations, common to abundant all year round. According to Ferrario \& Galván (1989) Thalassionema nitzschioides was reported by several authors (in some cases as Thalassiothrix nitzschioides) based on analysis carried out with light microscopy. Nevertheless, some specimens of Thalassionema pseudonitzschioides present a subtle heteropolarity and might have been misidentified as $T$. nitzschioides since critical diagnostic features as the morphology of the areola occlusions and the orientation of the labiate processes are not visible with light microscopy.

TABLE 2

Members of the family Thalassionemataceae found in the Buenos Aires Province. * New record for Argentina, $\mathrm{n} / \mathrm{d}$ no data

Miembros de la familia Thalassionemataceae encontrados en la Provincia de Buenos Aires. * Nuevo reporte para Argentina, $\mathrm{n} / \mathrm{d}$ sin datos

\begin{tabular}{|c|c|c|c|c|c|}
\hline Species & $\begin{array}{l}\text { Height of the } \\
\text { frustule }(\mu \mathrm{m})\end{array}$ & $\begin{array}{l}\text { Length } \\
(\mu \mathrm{m})\end{array}$ & $\begin{array}{l}\text { Width } \\
(\mu \mathrm{m})\end{array}$ & $\begin{array}{l}\text { Areolae } \\
(10 \mu \mathrm{m})\end{array}$ & Striking features \\
\hline Thalassionema frauenfeldii & $3,6-5,2$ & $55-103$ & $2,3-5$ & $6-9$ & $\begin{array}{l}\text { Valve outline linear, heteropolar, areolae } \\
\text { occluded by simple, unbrached arches }\end{array}$ \\
\hline Thalassionema nitzschioides & $2,3-2,8$ & $8-83$ & $2-4$ & $9-13$ & $\begin{array}{l}\text { Valve outline linear, isopolar, areolae } \\
\text { occluded by Y-shaped bars with lateral } \\
\text { branches }\end{array}$ \\
\hline Thalassionema pseudonitzschioides* & $2,5-6,7$ & 24-118 & $2,3-4$ & $8-12$ & $\begin{array}{l}\text { Valve outline linear, heteropolar, areolae } \\
\text { occluded by Y-shaped bars }\end{array}$ \\
\hline Thalassionema synedriforme $*$ & $2,4-3.3$ & $210-440$ & $2,4-5,6$ & $11-20$ & $\begin{array}{l}\text { Valve outline spatulate, heteropolar, } \\
\text { areolae occluded by Y-shaped bars with } \\
\text { lateral branches }\end{array}$ \\
\hline Lioloma pacificum* & $\mathrm{n} / \mathrm{d}$ & $476-626$ & $1,6-3,2$ & $13-16$ & $\begin{array}{l}\text { Valve outline linear, heteropolar, head } \\
\text { pole with spines, foot pole smoothly } \\
\text { tapering, areolae occluded by vela type } \\
\text { rota, with "bubble shaped" structures } \\
\text { and labiate processes "parrot-beak" }\end{array}$ \\
\hline
\end{tabular}




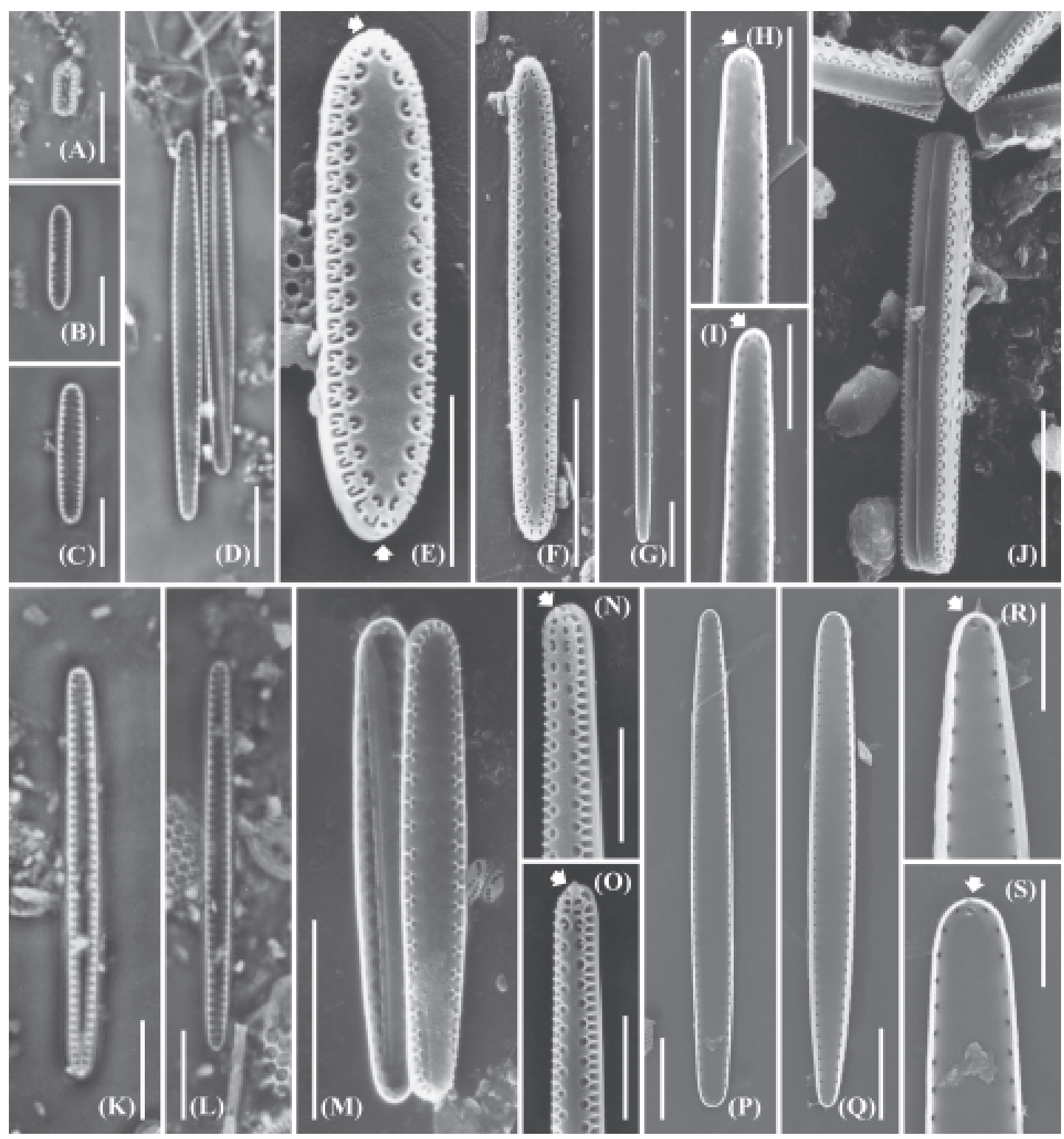

Fig. 3: Thalassionema nitzschioides. (A-D). LM: Valves of different sizes showing marginal areolae. (E-J). SEM. (E) and (F): Valves in external view. (E). The arrowhead shows the apical protrusion and the arrow the reinforced hole. $(\mathrm{G})$ : Valve in internal view. $(\mathrm{H})$ and (I): Both poles of valve in $(\mathrm{G})$ showing labiate processes in apical axis (arrowed). (J): Frustules in girdle view. (K-S). Thalassionema pseudonitzschioides. (K) and (L). LM: Valves showing marginal areolae. (M-S). SEM. (M): Valves of the same frustule. $(\mathrm{N})$ and $(\mathrm{O})$ : Both poles of the same valve in external view. $(\mathrm{N})$ : Broad end showing the reinforced hole (arrowed). (O): Narrow end with spine protrusion (arrowed). (P) and (Q): Valves in internal view. $(\mathrm{R})$ and $(\mathrm{S})$ : Both poles of valve in $(\mathrm{P})$. Note sessile labiate processes (arrowed). Scale bars: (A-D), (F), (G), (J-M), (P) and (Q) $=10 \mu \mathrm{m} ;(\mathrm{E}),(\mathrm{H}),(\mathrm{I})$, $(\mathrm{N}),(\mathrm{O}),(\mathrm{R})$ and $(\mathrm{S})=5 \mu \mathrm{m}$.

Thalassionema nitzschioides. (A-D). MO: Valvas de diferentes tamaños mostrando areolas marginales. (E-J). MEB. (E) y (F): Valvas en vista externa. (E). La punta de flecha muestra la protrusión apical y la flecha el orificio reforzado. (G): Valva en vista interna. (H) y (I): Polos de la valva de (G) mostrando procesos labiados ubicados según el eje apical (flechas). (J): Frústulos en vista conectival. (K-S). Thalassionema pseudonitzschioides. (K) y (L). MO: Valvas mostrando areolas marginales. (M-S). MEB. (M): Valvas del mismo frústulo. (N) y (O): Polos de la misma valva en vista externa. (N): Ápice ancho mostrando la abertura reforzada del proceso labiado (flecha). (O): Ápice estrecho con espina (flecha). (P) y (Q): Valvas en vista interna. (R) y (S): Polos de la misma valva correspondientes a (P). Note procesos labiados sésiles (flechas). Escalas: (A-D), (F), (G), (J-M), (P) y (Q) $=10 \mu \mathrm{m} ;(\mathrm{E}),(\mathrm{H}),(\mathrm{I}),(\mathrm{N}),(\mathrm{O}),(\mathrm{R})$ y $(\mathrm{S})=5 \mu \mathrm{m}$. 
Thalassionema pseudonitzschioides (Schuette \& Schrader) Hasle in Hasle \& Syvertsen (Fig. $3 K-S$, Table 2). Basionym: Thalassiothrix pseudonitzschioides Schuette \& Schrader

Hasle, 2001: 19-22, figs 28-42. Cells united by the ends into fan-shaped colonies by mucous pads. Frustule, rectangular in girdle view. Valve, linear in outline, with slightly dissimilar rounded poles, one of them wider than the other. Valve face flat or subtle undulated, with a wide sternum delimited by a marginal row of areolae placed between it and the valve mantle. Valve mantle unperforated, deep and almost perpendicular to the valve surface. Areolae, with an internal, circular, small foramen and an external depression partially occluded by Y-shaped bars. Labiate processes placed one at each pole of the valve. Externally they open by apical protrusions, the more prominent is spine-like (Fig. 3O arrowed) and the other is a reinforced hole (Fig. 3N arrowed). Some valves showed holes in both poles. Internally labiate processes present sessile lips, lying either oblique or almost perpendicular to the apical axis (Fig. $3 R$ and $3 S$ arrowed).

Remarks: as in the case of Thalassionema frauenfeldii we commonly found in our sampling specimens of $T$. pseudonitzschioides with a narrower range of length, wider and with greater areola density than that described by Hasle (2001).

Distribution in Argentina: $T$. pseudonitzschioides is a subtropical to temperate species (Hasle 2001) and it was found sporadically in all the stations of the studied area, scarce to common all year round, occasionally abundant in spring and fall. This species is recorded for first time for Argentina.

Thalassionema synedriforme (Greville) Hasle (Fig. 4A-G, Table 2). Basionym: Asterionella synedriformis Greville. Hasle, 1999: 54-58, figs 1-6, 8, 9; Hasle, 2001: 25-29, figs 68-84

Valve outline linear, slightly inflated in the middle, narrowed towards the head-pole than towards the foot-pole. Valve face flat, with a wide sternum delimited by a marginal row of areolae placed between it and the valve mantle. Valve mantle unperforated, deep and almost perpendicular to the valve surface. Areolae with internal, circular, small foramens and external depressions partially occluded by $\mathrm{Y}$ shaped bars with a varying number of lateral branches. Labiate processes placed one at each pole of the valve. Foot-pole rounded with the opening of the labiate process as large external hole placed close to the apex (Fig. 4E arrowed) and a marginal ridge formed by confluence of the areolae occlusion. Head-pole with an external, more prominent, hollow, arrowheadlike protrusion which is the external opening of the labiate process and areolae more densely disposed. Internally, the slit-like labiate process of the foot-pole lying almost parallel to the apical axis of the valve.

Remarks: Hasle (2001) pointed out that this taxon was reported by Frenguelli (1941) for Argentinean coastal waters. In this paper the author only enlists two taxa, Thalassiothrix frauenfeldi $\underline{i}$ Grunow and Thalassiothrix javanica (Grunow) Hustedt. The synonym list presented by Frenguelli for Thalassiothrix frauenfeldii includes Asterionella synedraeformis Greville, which is the basionym of Thalassionema synedriforme according to Hasle (2001). Frenguelli mentions that he found valves with 9-10 areolae in $10 \mu \mathrm{m}$, and illustrate a linear, fragmentary specimen that by the valve outline and areola density might be also attributed to Thalassionema frauenfeldii as the author proposed, but not to T. synedriforme. Additionally, in the case of Thalassiothrix javanica (Grunow) Hustedt, Frenguelli illustrates a specimen slightly heteropolar with 6-7 areolae in $10 \mu \mathrm{m}$ that differs in areola density and valve outline from Thalassionema synedriforme (12-16 areolae in $10 \mu \mathrm{m}$ according to Hasle 2001).

The few specimens found in our sampling show a greater range of areola density (11-20 areolae in $10 \mu \mathrm{m}$ ) than that presented by Hasle (2001).

Distribution in Argentina: Thalassionema synedriforme mentioned by Hasle (2001) as apparently restricted to tropical and subtropical waters was found in San Clemente del Tuyú, La Lucila del Mar and Villa Gesell, scarce in fall. This species is recorded by first time from Argentinean coastal waters.

Lioloma Hasle. The generytype of this genus by original designation is Lioloma elongatum (Grunow) Hasle in Hasle \& Syvertsen (1996) 


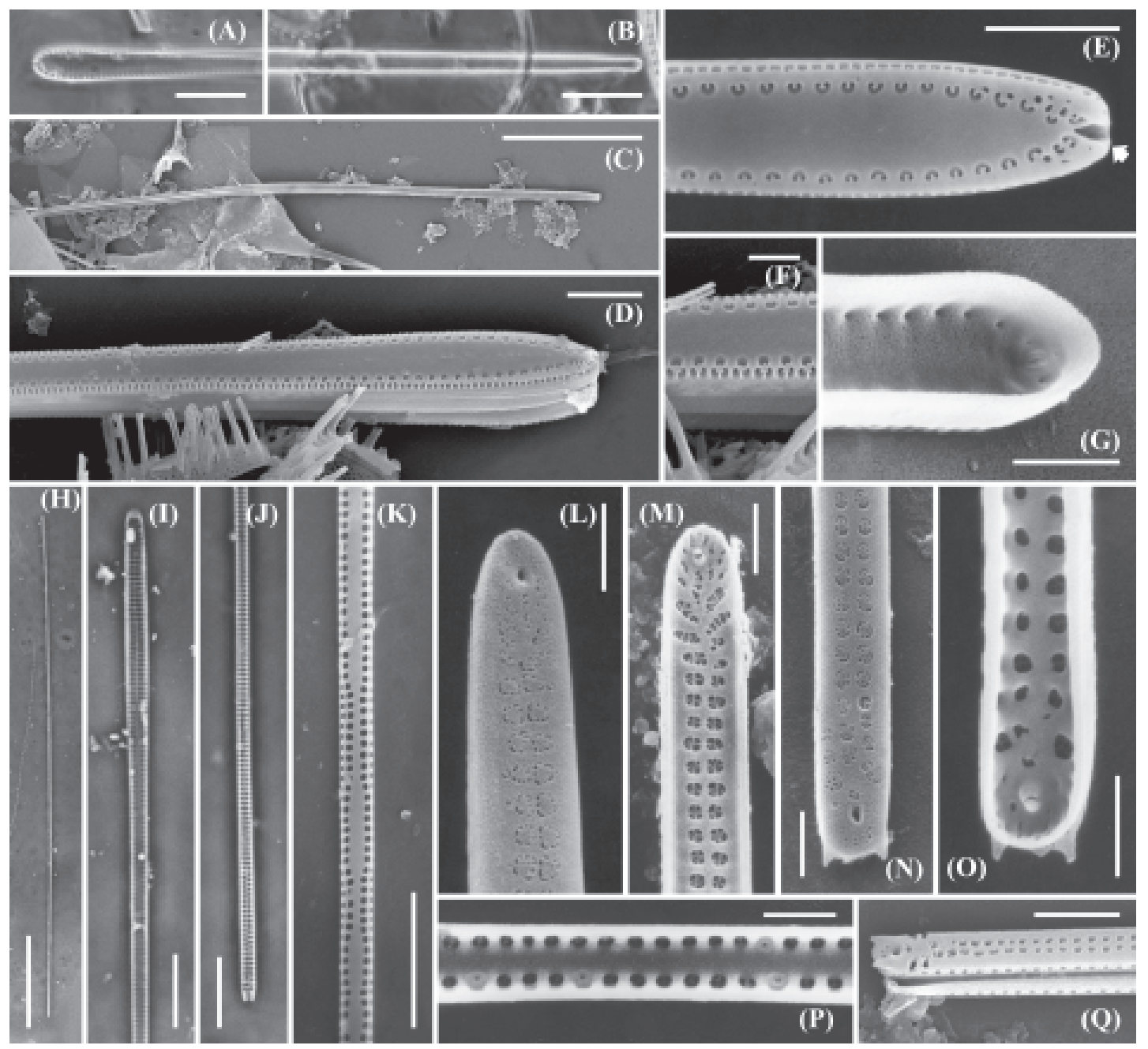

Fig. 4: Thalassionema synedriforme. (A) and (B). LM: Both poles of the same valve. (A): Wide, spineless "foot-pole" in valve view. (B): "Head-pole" in valve view with apical spine. (C-G). SEM. (C): Frustule in girdle view. (D): "Foot-pole" of frustule in girdle view. (E): Wide, spineless "footpole" in external view. Note the opening of the labiate process (arrowed). (F): Detail of the areola occlusions. (G): Internal view of the "foot-pole" showing labiate process. (H-Q): Lioloma pacificum. (H-J). LM. (H): Whole valve. (I): Wide "foot-pole" showing narrow sternum. (J): "Head-pole" with apical spines. (K-Q). SEM. (K): Central part of the valve in external view. Note that the areolar occlusions are lost. (L) and (M): Valves close up the "foot-pole". (L): External valve view showing the opening of the labiate process. (M). Internal valve view showing labiate process "parrot-beaklike". (N) and $(\mathrm{O})$ : "Head-poles" with two apical triangular more developed spines. (N): External valve view. $(\mathrm{O})$ : Internal valve view. $(\mathrm{P})$ : Detail of the valve in internal view showing "bubbleshaped" structures. (Q): Frustule apex. Note the areolate valve mantle. Scale bars: $(\mathrm{H})=100 \mu \mathrm{m} ;(\mathrm{C})$ $=50 \mu \mathrm{m} ;(\mathrm{A})$ and $(\mathrm{B})=20 \mu \mathrm{m},(\mathrm{I}-\mathrm{K})=10 \mu \mathrm{m} ;(\mathrm{D}),(\mathrm{E})$ and $(\mathrm{Q})=5 \mu \mathrm{m} ;(\mathrm{F}),(\mathrm{G}),(\mathrm{L}-\mathrm{P})=2 \mu \mathrm{m}$.

Thalassionema synedriforme. (A) y (B). MO: Polos de la misma valva. (A): Polo basal ancho y sin espina en vista valvar. (B): Polo apical en vista valvar con espina. (C-G). MEB. (C): Frústulo en vista conectival. (D): Polo basal del frústulo en vista conectival. (E): Polo basal ancho y sin espina en vista valvar externa. Note la abertura del proceso labiado (flecha). (F): Detalle de la oclusión de las areolas. (G): Vista interna del polo basal mostrando proceso labiado. (H-Q): Lioloma pacificum. (H-J). MO. (H): Valva. (I): Polo basal ancho mostrando sternum estrecho. (J): Polo apical con espinas. (K-Q). MEB. (K): Parte central de la valva en vista externa. Note que las oclusiones areolares están perdidas. (L) y (M): Valvas cerca del polo basal. (L): Vista externa de la valva mostrando abertura del proceso labiado. (M): Vista interna de la valva mostrando proceso labiado de tipo "parrot-beak". (N) y (O): Polo apical con dos espinas triangulares más desarrolladas. $(\mathrm{N})$ : Valva en vista externa. (O): Valva en vista interna. (P): Detalle de la valva en vista interna mostrando estructuras "bubble-shaped". (Q): Frústulo. Note las areolas del manto valvar. Escalas: $(\mathrm{H})=100 \mu \mathrm{m} ;(\mathrm{C})=50 \mu \mathrm{m} ;(\mathrm{A})$ y $(\mathrm{B})=20$ $\mu \mathrm{m}_{s}(\mathrm{I}-\mathrm{K})=10 \mu \mathrm{m} ;(\mathrm{D}),(\mathrm{E})$ y $(\mathrm{Q})=5 \mu \mathrm{m} ;(\mathrm{F}),(\mathrm{G}),(\mathrm{L}-\mathrm{P})=2 \mu \mathrm{m}$. 
Lioloma pacificum (Cupp) Hasle in Hasle \& Syvertsen (Fig. 4H-Q, Table 2). Basionym: Thalassiothrix mediterranea var. pacifica Cupp. Hasle \& Syvertsen, 1996: 254-257, pl. 53, figs a-e, pl. 54, fig. 2; Cupp, 1943: 185 186, fig. 136; Hasle, 2001: 63-69, figs 241$251,254-272$

Cells solitary, long, narrow and slightly curved and twisted. Valve linear, heteropolate, slightly inflated towards the foot-pole. Head-pole with two apical triangular more developed spines, sometimes with an additional one smaller. Sternum varying in width along the most part of the valve and narrow towards the poles. Areolae ordered in a single row on the valve towards the poles, forming short striae composed by two of them alternating with singles rows in the most part of the valve, and irregularly located in the valve apices. Valve mantle deep and vertical with a row of areolae placed near the valve margin. Areolae occluded by vela type rotae. Bubble-shaped structures irregularly distributed within the areola row, internally located in the place of a foramen. Labiate processes located close to the apices, one at each pole, externally opened in circular holes and internally with two unequal lips parrot-beak-like and slit lying almost perpendicular to the apical axis.

Remarks: specimens of Lioloma pacificum found in our sampling were generally solitaries, with a narrower range of length and greater areola density than that described by Hasle (2001). When material was studied with LM, the specimens showed some morphological similarity with the longer specimens of Thalassionema synedriforme concerning the needle-shaped valve, heteropolarity, and morphometric data. However, it is possible to distinguish both taxa considering the number of spines in the head-pole, two lateral in $L$. pacificum and only one central in $T$. synedriforme, the appearance and position of the labiate processes of the head-pole, conspicuous and placed on the valve surface in L. pacificum and inconspicuous and placed next to the apical margin in $T$. synedriforme. The ultrastructural analysis of the valves shows other crucial diagnostic features, as type of areolae occlusion, morphology of the labiate processes in internal view, presence or absence of bubble-shaped structures and morphology of the valve mantle.
Distribution in Argentina: Lioloma pacificum, a subtropical to temperate species (Hasle 2001), was found sporadically in all the stations, scarce to common all year round, more abundant in summer and fall. This species was previously reported by Hasle (2001) from oceanic waters of the South Atlantic Ocean

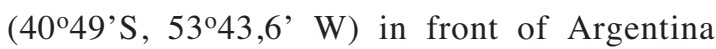
and is recorded for the first time from Argentinean coastal waters.

\section{Rhaphoneidaceae Forti}

Delphineis Andrews. The generytype of this genus by original designation is Delphineis angustata (Pantocsek) Andrews (1977).

Delphineis minutissima (Hustedt) Simonsen (Fig. 5A-J, Table 3). Basionym: Rhaphoneis minutissima Hustedt. Hustedt, 1939: 599, figs 14-15; Simonsen, 1987: 252, pl. 374, figs 1016; Ferrario et al. 2003: 126, fig. $3 j, k$

Cells solitary. Valves suborbicular, rhombicelliptical to elliptical-lanceolate, with rounded apices to slightly produced rounded apices. Valve face flat and smooth, valve mantle oblique and shallow, with a single row of areolae roughly of the same size and evenly spaced. Striae uniseriate, almost straight or slightly curved, perpendicular to radiate, no consistently aligned across the sternum. Areolae subrectangular, occluded by rotae placed near the inside of the valve. Submarginal row of areolae is continuous around the apices of the valve face. Externally, an irregular row of minute granules located between the areolae of the mantle and the submarginal row of areolae, encircles the valve surface. Sternun more or less narrow, linear to lanceolate, with pairs of tiny pores penetrating the valve at each end just inwards the apical striae. Labiate processes taking the place of one areola at each apex, either at the same or opposite sides of the sternum, sessile internally and opening by a pore, buttonhole-shaped externally (Fig. 5I and 5J arrowed).

Remarks: VanLandingham recognized Delphineis minutissima as valid, without giving any other references. This suggests that the taxa had not been cited in more general floras up to 1967. Although the absence of this species in the catalogues by 

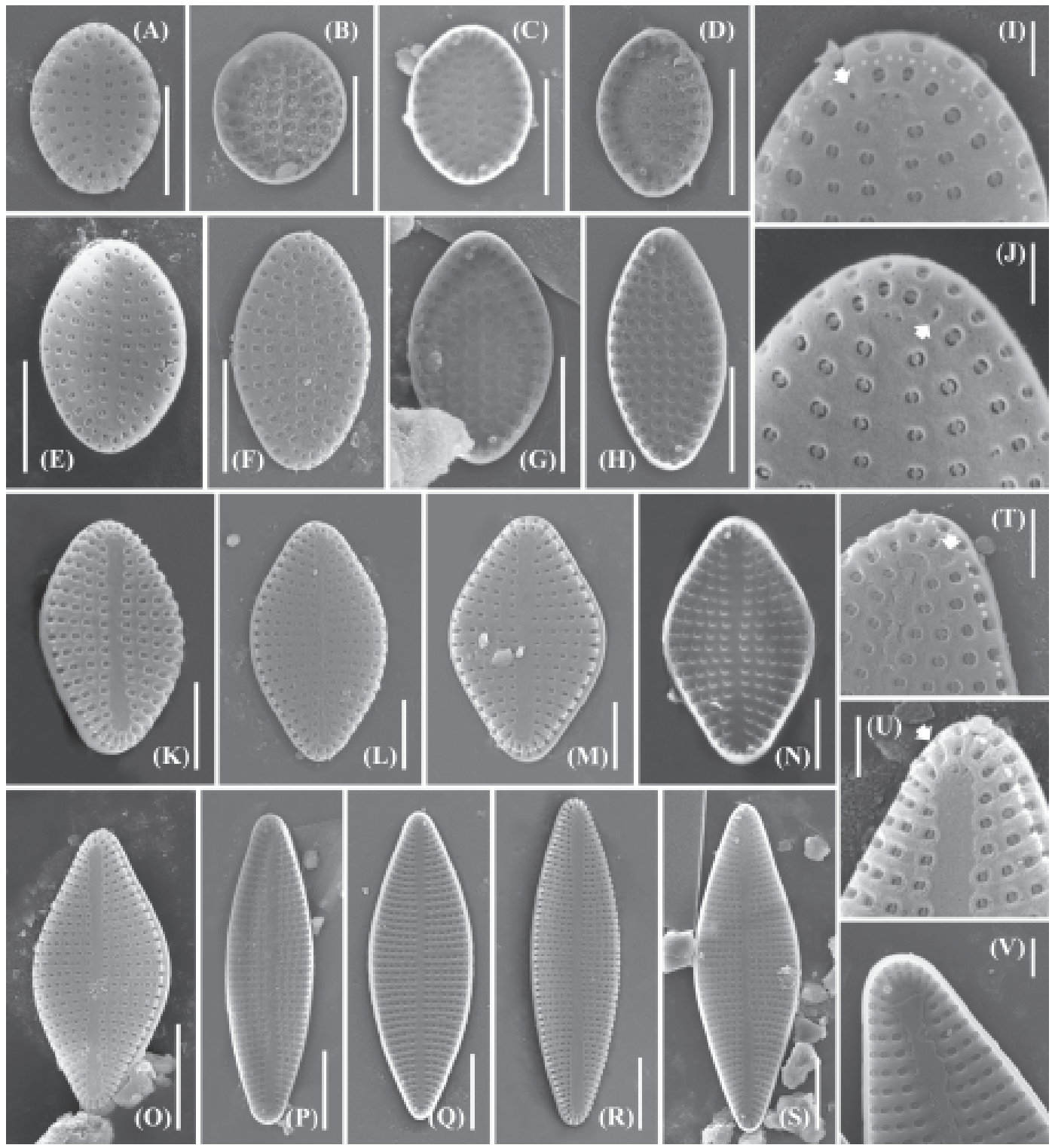

Fig. 5: Delphineis minutissima. SEM. (A-H): Size and morphological variability found in our material. (A), (E) and (F): Valves in external view. (B-D), $(\mathrm{G})$ and $(\mathrm{H})$ : Valves in internal view. Note differences in the position of the apical processes, at the same or opposite sides of the sterna. (I) and (J): Detail of two valves in external view. Note the opening of the labiate process buttonhole-shaped (arrowed) and the pair of tiny pores placed at the ends of the sterna. $(\mathrm{K}-\mathrm{V})$. Delphineis surirella. SEM. (K-S): Size and morphological variability found in our material. (K-M), (O) and (R): Valves in external view. $(\mathrm{N}),(\mathrm{P}),(\mathrm{Q})$ and $(\mathrm{S})$ : Valves in internal view. Note differences in the position of the apical processes, at the same or opposite sides of the sterna. (T-U): Detail of valves in external view. Note the opening of the labiate processes by a lip (arrowed). (V): Detail of a valve in internal view. Scale bars: $(\mathrm{O}-\mathrm{S})=10 \mu \mathrm{m} ;(\mathrm{A}-\mathrm{H}),(\mathrm{K}-\mathrm{N})=5 \mu \mathrm{m} ;(\mathrm{T}-\mathrm{V})=2 \mu \mathrm{m}$; (I) and $(\mathrm{J})=1 \mu \mathrm{m}$.

Delphineis minutissima. MEB. (A-H): Variabilidad de tamaño y morfología encontrada en nuestro material. (A), (E) y (F): Valvas en vista externa. (B-D), (G) y (H): Valvas en vista interna. Note diferencias en la posición de los procesos apicales, del mismo o en lados opuestos de los sterna. (I) y (J): Detalle de dos valvas en vista externa. Note la abertura de los procesos labiados en forma de ojal (flechas) y el par de diminutos poros ubicados al final de los sterna. (K-V). Delphineis surirella. MEB. (K-S): Variabilidad de tamaño y morfología encontrada en nuestro material. (K-M), (O) y (R): Valvas en vista externa. (N), (P), (Q) y (S): Valvas en vista interna. Note las diferencias en la posición de los procesos apicales. (T), (U): Detalle de valvas en vista externa. Note la abertura de los procesos labiados en forma de boca (flechas). (V): Detalle de la valva en vista interna. Escalas: $(\mathrm{O}-\mathrm{S})=10 \mathrm{~mm} ;(\mathrm{A}-\mathrm{H}),(\mathrm{K}-\mathrm{N})=5 \mathrm{~mm} ;(\mathrm{T}-\mathrm{V})=2 \mathrm{~mm} ;(\mathrm{I})$ y $(\mathrm{J})=1 \mathrm{~mm}$. 
Gaul et al. (1993) and Henderson \& Reimer (2003), suggests that (prior to 1999) there were no published studies with SEM about them, Ferrario et al. (2003) published an ultrastructural analysis of it. Morphological variability that they described is lower than that we found in our material. We analysed with SEM about forty specimens which presented a great variability in valve outline and morphometric parameters. The orbicular ones are smaller, with higher stria and areola density than those described by Hustedt in the protologue (14-16 striae in $10 \mu \mathrm{m})$, and resemble specimens described by Ferrario et al. (2003) (17-21 striae in $10 \mu \mathrm{m}, 18-21$ areolae in $10 \mu \mathrm{m})$. Elliptical-lanceolate and rhombicelliptical specimens are larger in general, with lower stria and areola density than the orbicular, and fit better with Hustedt's range. Besides, some specimens show a complete submarginal ring of granules and others a row of minute depressions, or granules and depressions alternating in the ring.

Distribution in Argentina: Delphineis minutissima, a cosmopolitan species (Witkowski et al. 2000), occurs sporadically at all the stations, scarce in spring, more abundant in fall and winter. The species was previously reported from Bahía Anegada, Monte Hermoso and Pehuen-có (Buenos Aires Province, Argentina) by Ferrario et al. (2003).

Delphineis surirella (Ehrenberg) Andrews (Fig. 5K-V, Table 3). Basionym: Zygoceros surirella Ehrenberg. Synonym: Rhaphoneis surirella (Ehrenberg) Grunow in Van Heurck Andrews, 1981: 81-90, pl. 1, figs. 1-5, pl. 2, figs. 6, 7; Andrews, 1975: 212: pl. 3, figs. 35-37 (as Rhaphoneis surirella)

Cells solitary. Valves rhombic-elliptical to elliptical-lanceolate, with produced bluntly rounded apices. Valve with smoothly flat to slightly grooved external surface, valve mantle oblique and very shallow. A single row of areolae roughly of the same size and evenly spaced is placed between the valve surface and the mantle. Striae uniseriate, almost straight or slightly curved, perpendicular in the centre to radiate in the most part of the surface, no consistently aligned across the sternum. Largest specimens with apical striae placed in the bottom of slightly depressed transverse grooves on the exterior of the valves. Areolae subrectangular, occluded by rotae placed near the inside of the valve. Submarginal row of areolae continuous around the valve apices. Externally, a regular row of minute granules is located between the areolae of the mantle in most part of the outline and between the mantle areolae and the submarginal row of areolae in the apices. Sternun more or less narrow, linear to lanceolate, slightly widened near the apices, with a pair of tiny pores penetrating the valve at each of the apices placed just inwards the apical striae. Labiate processes taking the place of one areola at each apex, either at the same or opposite side of the sternum, sessile internally and opening externally by a lip (Fig. $5 \mathrm{~T}$ and $5 \mathrm{U}$ arrowed).

Remarks: our Delphineis surirella specimens show a greater variability than described by Andrews (1981) concerning to the stria and areola density, to the valve surface, smoothly flat to slightly grooved, and to the position occupied by the external submarginal ring of granules. The fine morphology of smaller specimens in our samples resemble that described and illustrated by Andrews (1981) but show a higher stria and areola density, which range coincides better with the description given by Andrews (1975). Our largest specimens show the apical striae placed in distinctly depressed transverse grooves on the valve exterior. In the discussion of the emended description of Delphineis (Andrews 1981) he pointed out that "It has also been necessary to remove the requirement of the external transverse grooves.....accommodate the species Rhaphoneis surirella (Ehrenberg) Grunow in Delphineis". It is possible that Andrews did not observe with SEM the biggest specimens, considering that he only illustrates one specimen $(21 \mu \mathrm{m})$ in external view. Our specimens and Andrews' (1981), share the most striking feature, the external opening of the labiate processes lip-shaped, that allow to distinguish this species of other morphologically related as $D$. minutissima.

Distribution in Argentina: Andrews (1981) pointed out that presently $D$. surirella is common in shallow marine to brackish coastal waters cool to temperate. We found it scarce to common, sometimes very abundant, all year round, in all the sampling stations. Sar (1996) reported this taxon based on SEM analysis 
TABLE 3

Members of the family Rhaphoneidaceae found in the Buenos Aires Province

Miembros de la familia Rhaphoneidaceae encontrados en la Provincia de Buenos Aires

\begin{tabular}{|c|c|c|c|c|c|c|}
\hline Species & $\begin{array}{l}\text { Length } \\
\text { in }(\mu \mathrm{m})\end{array}$ & $\begin{array}{l}\text { Width } \\
\text { in }(\mu \mathrm{m})\end{array}$ & $\begin{array}{l}\text { Length/width } \\
\text { ratio }\end{array}$ & $\begin{array}{c}\text { Striae } \\
(10 \mu \mathrm{m})\end{array}$ & $\begin{array}{l}\text { Areolae } \\
(10 \mu \mathrm{m})\end{array}$ & Striking features \\
\hline Delphineis minutissima & $4-12.5$ & $3.4-8.45$ & $1.1-2$ & $13-20$ & $14-20$ & $\begin{array}{l}\text { Valve flat in external view. } \\
\text { Labiate processes externally } \\
\text { opening by a buttonhole shape } \\
\text { pores. Valve mantle presents a } \\
\text { single row of areolae that does } \\
\text { not reach the valve surface. Ring } \\
\text { of granules placed equidistant } \\
\text { between the row of submarginal } \\
\text { areolae of the valve face and the } \\
\text { areolae of the valve mantle. }\end{array}$ \\
\hline Delphineis surirella & $12.4-46$ & $7-15.5$ & $1.5-3.6$ & $8-12$ & $10-15$ & $\begin{array}{l}\text { Valve with smoothly flat to } \\
\text { slightly groove external surface. } \\
\text { Labiate processes externally lip } \\
\text { shaped. Valve mantle single row } \\
\text { of areolae reaches the valve } \\
\text { surface in the most part of the } \\
\text { outline. Ring of granules closer } \\
\text { the row of the mantle areolae } \\
\text { than the submarginal one. }\end{array}$ \\
\hline _Rhaphoneis amphiceros & $12.6-87.6$ & $9.9-26$ & $1.2-3.3$ & $6-10$ & $8-11$ & $\begin{array}{l}\text { Valves suborbicular, broad } \\
\text { elliptical to lanceolate-rhombic, } \\
\text { with slightly rostrate to } \\
\text { produced rostrate apices. }\end{array}$ \\
\hline
\end{tabular}

from other coastal environments of Argentina (Banco Reparo and Las Grutas, Río Negro Province) and several authors without SEM analysis reported it as fossil and recent from several locations of Argentina (see Ferrario \& Galván 1989 and Vouilloud 2003).

Rhaphoneis Ehrenberg. The generytype of this genus Rhaphoneis amphiceros (Ehrenberg) Ehrenberg, designated by Boyer (1927) Rhaphoneis amphiceros (Ehrenberg) Ehrenberg (Fig. 6A-R, Table 3). Basionym: Cocconeis amphiceros Ehrenberg. Synonym: Rhaphoneis amphiceros var. rhombica Grunow in Van Heurck. Rhaphoneis rhombica (Grunow) Andrews. Andrews, 1975: 204-205, pl. 1, figs. 912 (as R. amphiceros), : 210-211, pl. 2, figs. 33, 34 (as R. rhombica); Hasle \& Syvertsen, 1996: 252, pl. 52

Cells solitary. Valves suborbicular, broad elliptical to rhombic- lanceolate, with slightly rostrate to produced rostrate apices. Valve face flat, valve mantle shallow with a single row of areolae, smaller towards the apices. Striae uniseriate, almost straight or curved, perpendicular to or radiating from a narrowly lanceolate sternum. Areolae subrectangular to subcircular, occluded by external vela with concentric slits, like perforate rotae. Apical pore fields small, composed by roundish poroids more or less densely disposed. Labiate processes one per pole, placed either close or in the apical pore fields, sessile internally, and opening externally by a simple pore more or less distinguishable from the porelli.

Remarks: in our sampling we found numerous specimens with a great variability in valve outline and morphometric parameters. Several orbicular specimens with no produced apices, are smaller, with a length/width ratio between 1.2-1.4, and higher stria density than those reported by Andrews (1975) and Hasle \& Syvertsen (1996) as Rhaphoneis amphiceros. Other group of specimens fits with $R$. rhombica (Grunow) Andrews (Andrews 1975) in the 

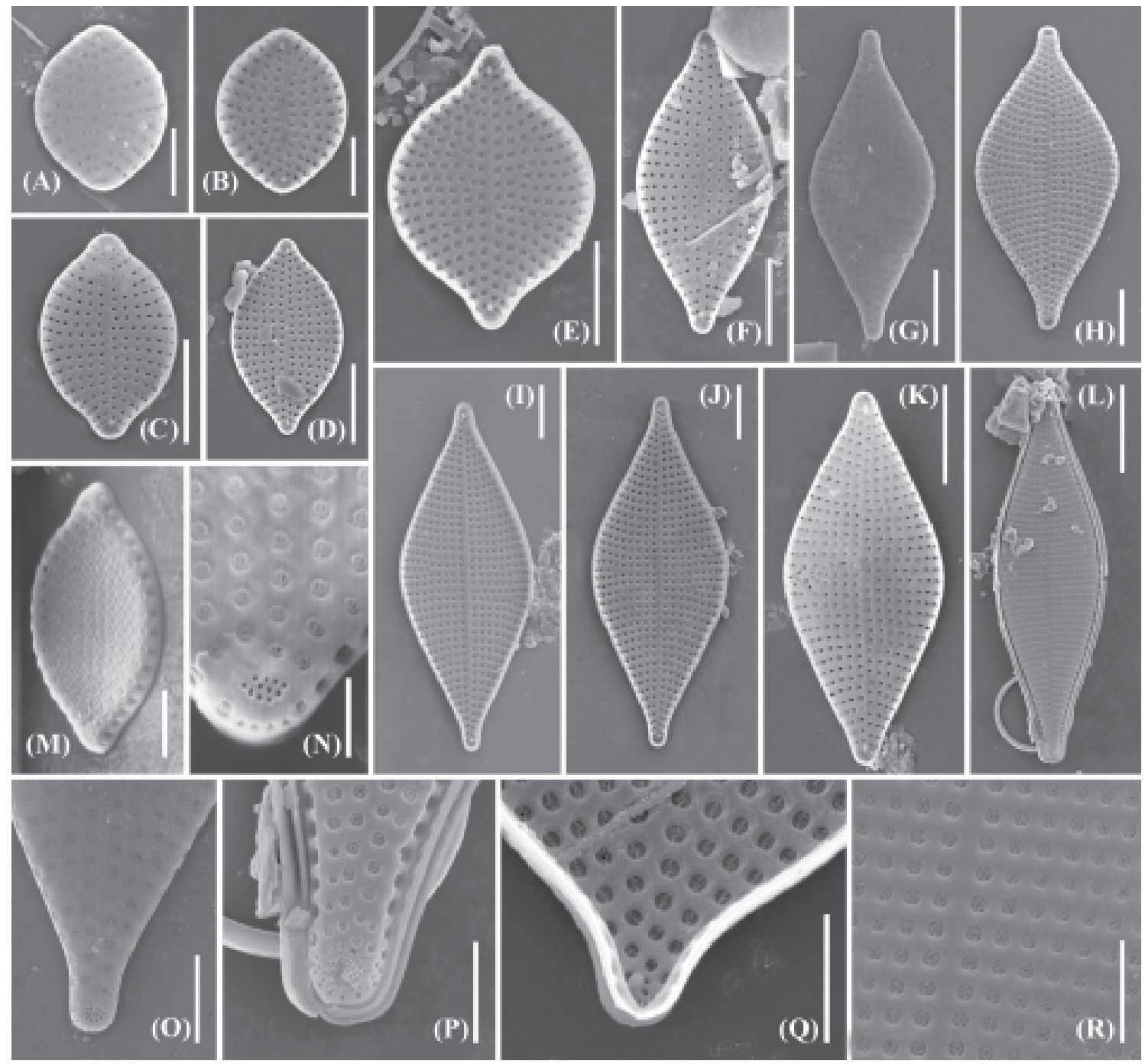

Fig. 6: Rhaphoneis amphiceros. SEM. (A-L): Size and morphological variability found in our material. (A), (G), (H) and (L): Valves in external view. (B-F, I-K): Valves in internal view. (M): Tilted valve, valve mantle with a single row of areolae. $(\mathrm{N})$ : Detail of the apex of $(\mathrm{M})$. Note that the external opening of the labiate process is not distinguishable from the porelli. $(\mathrm{O})$ : Detail of $(\mathrm{G})$. Note the external opening of the labiate process placed in the apical pore field. $(\mathrm{P})$ : Detail of $(\mathrm{L})$. Note the external opening of the labiate process placed out of the apical pore field. (Q): Detail of the apex in internal view showing areolae occluded by vela with concentric slits. $(\mathrm{R})$ : Detail of the valve surface of (L). Scale bars: (K), (L) $=20 \mu \mathrm{m}$; (C-J) $=10 \mu \mathrm{m}$; (A), (B), (M), (O-R) $=5 \mu \mathrm{m} ;(\mathrm{N})=1 \mu \mathrm{m}$.

Rhaphoneis amphiceros. MEB. (A-L): Variabilidad de tamaño y morfología encontrada en nuestro material. (A), (G), (H) y (L): Valvas en vista externa. (B-F, I-K): Valvas en vista interna. (M): Valva inclinada, manto valvar con una única hilera de areolas. $(\mathrm{N})$ : Detalle del ápice de $(\mathrm{M})$. Note que la abertura externa del proceso labiado no es distinguible de los porelli. $(\mathrm{O})$ : Detalle de $(\mathrm{G})$. Note la abertura externa del proceso labiado ubicada en el campo de poros. (P): Detalle de (L). Note la abertura externa del proceso labiado ubicada fuera del campo de poros. (Q): Detalle del ápice en vista interna mostrando los velos con rajaduras concéntricas. (R): Detalle de la superficie valvar de $(\mathrm{L})$. Escalas: $(\mathrm{K})$ y $(\mathrm{L})=20 \mu \mathrm{m} ;(\mathrm{C}-\mathrm{J})=10 \mu \mathrm{m}$; (A), (B), (M), (O-R) $=5 \mu \mathrm{m} ;(\mathrm{N})=1 \mu \mathrm{m}$. 
morphometric data, but presents $7-8$ striae in 10 $\mu \mathrm{m}$ (instead of 8-9), and the range of length/ width ratio is wider than previously given (Andrews 1975; Grunow in Van Heurck 1880 as $R$. amphiceros var. rhombica, pl. 36, figs. $20,21)$. We also found another group of specimens, less abundant in our sampling, that fits in valve outline and morphometric data with those described and illustrated by Andrews (1975) as $R$. amphiceros. When we analysed all these morphotypes with SEM, we could determine that they share the ultrastructural features. Based on this analysis, in the fact that smaller specimens present higher stria density than the larger ones (as is common in other diatom genera), and in the great variation of valve outline described for $R$. amphiceros (Hustedt 1931, Hendey 1964), we agree with the Hustedt's criterion (1931) who includes $R$. amphiceros var. rhombica in the synonymy of $R$. amphiceros. The argument used by Andrews (1975) to raise Grunow's variety to specific level was "that more is to be gained in stratigraphic diatom work by emphasizing, rather than ignoring differences", however, in the light of the present SEM analysis we think it is not sustainable.

Distribution in Argentina: Rhaphoneis amphiceros, a cosmopolitan species according to Hasle \& Syvertsen (1996), was found in all the stations, scarce to common, all year round, more abundant in winter. This species was previously reported without SEM analysis as fossil and recent from several places of Argentina (Ferrario \& Galván 1989, Vouilloud 2003).

\section{CONCLUSIONS}

Arraphid diatoms with needle-shaped valves of the family Thalassionemataceae, are present in the phytoplankton of the Buenos Aires coastal waters all year round. The species found in all stations, scarce to abundant were Thalassionema nitzschioides, $T$. frauenfeldii, $T$. pseudonitzschioides and Lioloma pacificum, while $T$. synedriforme was found only occasionally in fall. We confirm the presence of $T$. frauenfeldii and $T$. nitzschioides, previously reported from the area based on analysis carried out with light microscopy, and we report $T$. pseudonitzschioides, $T$. synedriforme and Lioloma pacificum for the first time for Argentina. We propose extending the distribution of $T$. synedriforme, originally restricted to tropical and subtropical waters, to temperate waters.

Based on our ultrastructural analysis we have established similarities in fine morphology among all the specimens of Thalassionema nitzschioides, including the smaller ones that fit with Thalassionema nitzschioides var. parva. Hasle (2001) pointed out that the variety "is distinctive not only in valve outline and cell length but also in distribution, being consistently reported from the tropical and subtropical areas". Considering that smallest specimens, which range is between 8-20 $\mu \mathrm{m}$ in length, are present in the temperate coastal waters of the Buenos Aires Province, we conclude that this variety is not sustainable and has to be synonymized with $T$. nitzschioides.

In the study area it is common to find specimens of the analysed taxa of Thalassionemataceae with a length range narrower than that given by Hasle (2001), and most of them are close to the inferior limit of this range. Furthermore, our Thalassionema species show larger areola density than described, therefore we propose the range has to be enlarged (Table 2). The diagnostic features that allow us to differentiate species of Thalassionemataceae present in coastal waters of the Buenos Aires Province are: valve outline, polarity of the valves, and morphology of the poles, areola occlusion and labiate processes (Table 2).

The other arraphid diatoms commonly present in the phytoplankton of the study area belong to the family Rhaphoneidaceae. According to Hasle \& Syvertsen (1996), the members of this family live in shallow coastal waters over sandy shores, and may be stirred up in turbulent waters becoming part of the plankton. The species found in all stations, scarce to abundant were Delphineis minutissima, D. surirella and Rhaphoneis amphiceros.

Based on the ultrastructural analysis of numerous specimens of both allied species of Delphineis, we determine the following diagnostic features: external morphology of the labiate processes, position of the mantle areolae, and position of the external ring of granules (Table 3 ). In spite of a certain 
similarity with the smaller specimens of $D$. surirella in morphometric parameters, the largest specimens of D. minutissima should be reliably determined with SEM considering that the external pore of the labiate processes is buttonhole-shaped, the valve mantle presents a single row of areolae that does not reach the valve surface, and the external ring of granules (or depressions) is equidistant between the row of the valve mantle areolae and the submarginal row of valve face areolae. Delphineis surirella shows the next combination of characters: the labiate processes are externally lip-shaped, the single row of areolae of the valve mantle reaches the valve surface in the most part of the outline and the external ring of granules (or depressions) is closer to the row of the mantle areolae than the submarginal one.

The range of the morphometric parameters of Delphineis minutissima and D. surirella has to be enlarged (Table 3).

Delphineis surirella and D. minutissima resemble $D$. surirelloides (Simonsen) Andrews in morphometric parameters and differs in valve outline. The latter species was erected by Simonsen (1974, as Rhaphoneis surirelloides) based on material from the Indian Ocean. In the protologue Simonsen compared this species with $D$. surirella and pointed out that both differ in valve outline, nevertheless he did no compare the new taxon with $D$. minutissima. Thus, D. surirelloides needs further examination of their type material to accurately establish its identity and to determine its specific limit.

Rhaphoneis amphiceros is another species frequently found in our sampling, scarce to common, all year round, with a great variability in valve outline and morphometric parameters. The ultrastructural analysis of numerous specimens allows us to establish similarities in areola density and fine morphology among all the specimens of $R$. amphiceros, including the smaller ones that fit with $R$. rhombica. Considering that the smallest specimens intergraded with the largest and that the distinction is not possible if the intermediate forms are contained as part of the analysis, we agree with the criterion of Hustedt (1931) who includes $R$. amphiceros var. rhombica in the synonymy of $R$. amphiceros. Thus, the range of morphometric data of this species has to be enlarged (Table 3).
Finally, as a general conclusion we point out the pressing need to include in the taxonomical study of any taxa the analysis of numerous specimens in order to evaluate the intraspecific variability and to establish accurately the specific limits.

\section{ACKNOWLEDGEMENTS}

We wish to acknowledge to Dr. Silvia Sala for the critical review of the manuscript and to three anonymous reviewers for improving our manuscript. This study was supported by Grants of CIC de la Provincia de Buenos Aires and CONICET.

\section{LITERATURE CITED}

ANDREWS GW (1975) Taxonomy and stratigraphic occurrence of the marine diatom genus Rhaphoneis. In: Simonsen R (ed) Third symposium on recent and fossil marine diatoms: 193-227. Nova Hedwigia, Beih

ANDREWS GW (1977) Morphology and stratigraphic significance of Delphineis, a new marine diatom genus. In: Simonsen R (ed) Fourth symposium on recent and fossil marine diatoms: 243-260. Nova Hedwigia, Beih

ANDREWS GW (1981) Revision of the diatom Genus Delphineis and morphology of Delphineis surirella (Ehrenberg) GW Andrews, n. comb. In: Ross R (ed) Sixth symposium on recent and fossil diatoms: 8192. Koeltz Scientific Books, Koenigstein, Germany.

ANDREWS GW (1988) Evolutionary trends in the marine diatom genus Delphineis GW Andrews. In: Round F (ed) Proceedings of the $9^{\text {th }}$ international diatom symposium: 197-206. Koeltz Scientific Books, Koenigstein, Germany.

BOYER CS (1927) Synopsis of North American Diatomaceae. Part I. Coscinodiscatae, Rhizoselenatae, Biddulphiatae, Fragilariatae. Proceedings of the Academy of Natural Sciences of Philadelphia, supplement (USA) 78: 1-228.

CUPP EE (1943) Marine plankton diatoms of the west coast of North America. Bulletin of the Scripps Institution of Oceanography of the University of California (USA) 5: 1-238

FERRARIO ME \& NM GALVÁN (1989) Catálogo de las diatomeas marinas citadas entre los $36^{\circ}$ y $\operatorname{los} 60^{\circ} \mathrm{S}$ con especial referencia al mar argentino. Publicación 20, Dirección Nacional del Antártico, Buenos Aires, Argentina. 327 pp

FERRARIO ME, EA SAR \& SE SALA (1995) Metodología básica para el estudio del fitoplancton con especial referencia a las diatomeas. In: Alveal K, ME Ferrario, EC Oliveira EC \& E Sar (eds) Manual de métodos ficológicos: 1-23. Ediciones Universidad de Concepción, Concepción, Chile.

FERRARIO ME, G ALMANDOZ, I GARIBOTTI \& S LICEA (2003) Nuevos registros de diatomeas típicas de sedimento en el plancton de la costa del mar argentino. Boletín de la Sociedad Argentina de Botánica (Argentina) 38: 123-29. 
FOURTANIER E \& JP KOCIOLEK (1999) Catalogue of the diatom genera. Diatom Research 14: 1-190.

FRENGUELLI J (1941) XVI Contribución al conocimiento de las diatomeas argentinas. Diatomeas del Río de La Plata. Revista del Museo de La Plata (n.s.) Botánica (Argentina) 15: 213-334.

GAUL U, U GEISSLER, M HENDERSON, R MAHONEY \& CW REIMER (1993) Bibliography on the finestructure of diatom frustules (Bacillariophyceae). Proceedings of the Academy of Natural Sciences of Philadelphia (USA) 144: 69-238.

GREUTER W, J MCNEILL, FR BARRIE, HM BURDET, $V$ DEMOULIN, TS FILGUEIRAS, DH NICOLSON, PC SILVA, JE SKOG, P TREHANE, NJ TURLAND \& DL HAWKSWORTH (2000) International code of botanical nomenclature (St. Louis Code). Regnum Vegetabile 138: 1-174.

HASLE GR (1999) Thalassionema synedriforme comb. nov. and Thalassiothrix spathulata sp. nov., two marine, planktonic diatoms from warm waters. Phycologia 38: 54-59.

HASLE GR (2001) The marine, planktonic diatom Family Thalassionemataceae: morphology, taxonomy and distribution. Diatom Research 16: 1-82.

HASLE GR \& GA FRYXELL (1970) Diatoms: cleaning and mounting for light and electron microscopy. Transactions of the American Microscopical Society 89: 469-474.

HASLE GR \& EE SYVERTSEN (1996) Marine diatoms. In: Tomas CR (ed) Identifying marine phytoplankton: 5-385. Academic Press, San Diego, California, USA.

HALLEGRAEFF GM (1986) Taxonomy and morphology of the marine plankton diatoms Thalassionema and Thalassiothrix. Diatom Research 1: 57-80.

HENDERSON MV \& CW REIMER (2003) Bibliography on the fine structure of diatom frustules (Bacillariophyceae). II. (+Deletions, addenda and corrigenda for bibliography I). Diatom Monographs 3: 1-377.

HENDEY NI (1964) An introductory account of the smaller algae of British coastal waters. Part V. Bacillariophyceae (Diatoms). Her Majesty Stationery Office, London, United Kingdom. 317 pp.

HUSTEDT F (1931) Die Kieselalgen Deutschlands, Österreichs und der Schweiz. In: Rabenhorsts L (ed) Kryptogamenflora von Deutschland, Österreichs und der Schweiz. Akademische Verlagsgesellschaft m.b.H. Leipzig 7: 177-464.

HUSTEDT F (1939) Die Diatomeenflora des Küstengebietes der Nordsee vom Dollart bis zur Elbemündung. I. Die Diatomeenflora in den Sedimenten unteren Ems sowie auf den Watten der Leybucht, des Memmert und bei der Insel Juist.
Abhandlungen Naturwissenschaftlicher Verein zu Bremen 31: 572-677.

MORENO RUIZ JL \& S LICEA (1995) Observations on the valve morphology of Thalassionema nitzschioides (Grunow) Hustedt. In: Marino D \& M Montresor (eds) Proceedings of the $13^{\text {th }}$ International Diatom Symposium: 393-413. Biopress Limited, Bristol, United Kingdom.

PRYGIEL J \& M COSTE (2000) Guide méthodologique pour la mise en ouvre de l'indice biologique diatomées. Agences de l'Eau, Ministiére de l'Amnagement du Territoire et de l'Environment, Direction de 1'Eau \& CEMAGREF, Paris, France. $134 \mathrm{pp}$.

REID FMH \& FE ROUND (1987) The Antarctic diatom Synedra reinboldii: taxonomy, ecology and transference to a new genus, Trichotoxon. Diatom Research 2: 219-227.

ROSS R, COX EJ, NI KARAYEVA, DG MANN, TBB PADDOCK, R SIMONSEN \& PA SIMS (1979) An amended terminology for the siliceous components of the diatom cell. Nova Hedwigia Beih 64: 513533.

ROUND FE, RM CRAWFORD \& DG MANN (1990) The diatoms. Biology and morphology of the genera. Cambridge University Press, Cambridge, United Kingdom. 747 pp.

SAR EA (1996) Flora diatomológica de Bahía San Antonio (Prov. de Río Negro, Argentina) Orden Pennales I. Revista del Museo de La Plata (n. s.) 14, Botánica (Argentina) 107: 399-432.

SILVA PS \& GR HASLE (1997) Proposal to conserve the name Synedra nitzschioides (Bacillariophyceae) with a conserved type to preserve the correct application of the generic name Thalassionema. Taxon 46: 331-332.

SIMONSEN R (1974) The diatom plankton of the Indian Ocean expedition of RV "Meteor" 1964-1965. "Meteor" Forschungsergebnisse, Reihe D 19: 1-107.

SIMONSEN R (1987) Atlas and catalogue of the diatom types of Friedrich Hustedt. Text (525 pp.), Atlas (772 plates). J. Cramer, Berlin, Germany.

VAN HEURCK H (1880) Synopsis des diatomées de Belgique. Atlas, Pls 1-30. Ducaju \& Cie, Anvers, France.

VANLANDINGHAM SL (1969) Catalogue of the fossil and recent genera and species of diatom and their synonyms. Part III. Coscinophaena through Fibula:1087-1756. J. Cramer, Lehre, Germany.

VOUILLOUD AA (2003) Catálogo de diatomeas continentales y marinas de Argentina. Asociación Argentina de Ficología, La Plata, Argentina. 310 pp.

WITKOWSKI A, H LANGE-BERTALOT \& D METZELTIN (2000) Diatom flora of marine coasts I. Iconographia Diatomologica 7: 1-925. 
